\title{
MENINGKATKAN KOMPETENSI GURU DALAM MENYUSUN SILABUS DAN RPP MELALUI SUPERVISI AKADEMIK YANG BERKELANJUTAN DI SD NEGERI LIUNGGUNUNG
}

\author{
Eros Rosita \\ SD Negeri Liunggunung, Mangkubumi, Tasikmalaya, Indonesia \\ Email: rokayahya34@gmail.com
}

\begin{abstract}
Based on the results of observations, it is known that the competence of teachers in compiling syllabus and lesson plans is still low, which requires the principal to carry out academic supervision on an ongoing basis in order to increase teacher competence in the planning, implementation and evaluation of learning processes. The purpose of this study was to determine: 1) sustainable academic supervision is able to improve teacher competence in compiling syllabus and lesson plans; and 2) The steps for providing academic supervision can improve teacher competence in compiling syllabus and lesson plans. The subjects of this study were teachers of SD Negeri Liunggunung, Mangkubumi District, Tasikmalaya City. This research was conducted with a classroom action research method that lasted for 2 cycles. Each cycle consists of planning, implementation, observation and reflection stages. The results showed that ongoing academic supervision was scientifically proven to improve teacher competence in compiling syllabus and lesson plans at SD Negeri Liunggunung, Mangkubumi District, Tasikmalaya City. This is evidenced by the increase in the number of good teacher syllabi from $30 \%$ to $80 \%$ after academic supervision. In addition, the number of good quality RPPs also increased from $30 \%$ to $90 \%$.
\end{abstract}

Keywords: Teacher Competence, Preparing Syllabus and RPP, Continuous Academic Supervision

\begin{abstract}
ABSTRAK
Berdasarkan hasil observasi diketahui bahwa kompetensi guru dalam menyusun Silabus dan RPP masih rendah. Hal ini menuntut kepala sekolah untuk melakukan supervise akademik secara berkelanjutan agar dapat meningkatkan kompetensi guru dalam proses perencanaan, pelaksanaan dan evaluasi pembelajaran. Tujuan dari penelitian ini adalah untuk mengetahui: 1) supervise akademik yang berkelanjutan yang mampu meningkatkan kompetensi guru dalam menyusun silabus dan RPP; dan 2) langkah-langkah pemberian supervise akademik yang dapat meningkatkan kompetensi guru dalam menyusun silabus dan RPP. Subjek penelitian ini adalah guru-guru SD Negeri Liunggunung Kecamatan Mangkubumi Kota Tasikmalaya. Penelitian ini dilakukan dengan metode penelitian tindakan kelas yang berlangsung selama 2 siklus. Masing-masing siklus terdiri dari tahapan perencanaan, pelaksanaan, observasi dan refleksi. Hasil penelitian menunjukkan bahwa supervisi akademik secara berkelanjutan terbukti secara ilmiah dapat meningkatkan kompetensi guru dalam menyusun silabus dan RPP di SD Negeri Liunggunung Kecamatan Mangkubumi Kota Tasikmalaya. Ini terbukti dengan meningkatnya jumlah silabus guru yang baik dari $30 \%$ menjadi $80 \%$ setelah supervise akademik. Selain itu jumlah RPP yang berkualitas baik juga meningkat dari 30\% menjadi $90 \%$.
\end{abstract}

Kata Kunci: Kompetensi Guru, Menyusun Silabus dan RPP, Supervisi Akademik yang Berkelanjutan

Cara sitasi: Rosita, E. (2021). Meningkatkan Kompetensi Guru dalam Menyusun Silabus dan RPP melalui Supervisi Akademik yang Berkelanjutan di SD Negeri Liunggunung. J-KIP (Jurnal Keguruan dan IImu Pendidikan), 2 (1), 1-8. 


\section{PENDAHULUAN}

Pendidikan merupakan hal penting dalam rangka meningkatkan kualitas Sumber Daya Manusia baik dari segi spiritual, intelegensi, maupun skill untuk menunjang kehidupannya (Sopiah, et.al. 2020). Oleh karena itu, guru adalah pendidik profesional dengan tugas utama mendidik, mengajar, membimbing, mengarahkan, melatih, menilai, dan mengevaluasi peserta didik pada pendidikan anak usia dini jalur pendidikan formal, pendidikan dasar, dan pendidikan menengah (PP Nomor 74 Tahun 2008). Peraturan Menteri Pendidikan Nasional Nomor 16 Tahun 2007 serta Peraturan Pemerintah Nomor 74 Tahun 2008 tentang Guru, mengamanatkan bahwa guru wajib memiliki kompetensi pedagogik, kompetensi kepribadian, kompetensi sosial, dan kompetensi profesional.

Kompetensi padagogik merupakan kemampuan dalam mengelola peserta didik, kompetensi kepribadian dan kompetensi sosial merupakan kemampuan pendidik sebagai bagian dari masyarakat, serta kompetensi profesional merupakan kemampuan guru dalam menguasai bidang ilmu pengetahuan, teknologi, dan/atau seni dan budaya yang diampu sekurang-kurangnya meliputi penguasaan materi pelajaran secara luas dan mendalam sesuai dengan standar isi program satuan pendidikan, mata pelajaran, dan/atau kelompok mata pelajaran yang akan diampu.

Menurut Danim (2002), untuk melihat tingkat kemampuan profesional guru dilakukan melalui dua perspektif, yaitu melalui tingkat pendidikan minimal dari latar belakang pendidikan untuk jenjang sekolah tempat guru tersebut dan penguasaan guru terhadap materi bahan ajar, mengelola proses pembelajaran, mengelola siswa, serta melaksanakan tugas-tugas bimbingan.

Kompetensi profesional guru dapat ditingkatkan melalui bimbingan dan pelatihan oleh kepala sekolah maupun pengawas sekolah melalui kegiatan supervisi akademik dan pelatihan profesional guru. Berdasarkan Permenpan dan Reformasi Birokrasi No.21 Tahun 2010, menyatakan dalam kedudukan dan fungsinya, pengawas adalah penanggungjawab utama atas terjadinya pembinaan sekolah sesuai dengan jenis dan jenjang lembaganya. Pengawas sekolah dalam konteks ini memiliki tanggungjawab melaksanakan supervisi sehingga mampu meningkatkan kemampuan guru-guru dalam membimbing prestasi siswa di sekolah. Supervisi adalah melihat bagian mana dari kegiatan di sekolah yang masih negatif untuk diupayakan menjadi positif, dan melihat mana yang sudah positif untuk dapat ditingkatkan menjadi lebih positif lagi, yang penting adalah pembinaan (Arikunto, 2006).

Supervisi akademik bukanlah penilaian unjuk kerja guru, apalagi bila tujuan utama penilaiannya semata-mata hanya dalam arti sempit, yaitu mengkalkulasi kualitas keberadaan guru dalam memenuhi kepentingan akreditasi guru belaka (Bahri, 2014). Perencanaan program berfungsi untuk memberikan arah pelaksanaan pembelajaran sehingga menjadi terarah dan efisien. Salah satu bagian dari perencanaan pembelajaran yang sangat penting dibuat oleh guru sebagai pengarah pembelajaran adalah silabus dan Rencana Pelaksanaan Pembelajaran (RPP). Rencana Pelaksanaan Pembelajaran ini dibuat untuk memandu guru dalam mengajar agar tidak melebar jauh dari tujuan pembelajaran.

Dengan melihat pentingnya penyusunan perencanaan pembelajaran ini, guru semestinya tidak mengajar tanpa adanya rencana. Hasil pengamatan di SD Negeri Liunggunung Kecamatan Mangkubumi Kota Tasikmalaya didapatkan data sebagai berikut:

1. Hanya $60 \%$ guru yang menyusun silabus dan RPP

2. Secara kualitas, silabus dan RPP yang baik baru mencapai angka $30 \%$ dari silabus dan RPP yang dibuat oleh guru.

Oleh sebab itu rumusan masalah dalam penelitian ini adalah:

1. Apakah supervise akademik yang berkelanjutan mampu meningkatkan kompetensi guru dalam menyusun silabus dan RPP?

2. Bagaimana langkah-langkah pemberian supervise akademik dapat meningkatkan kompetensi guru dalam menyusun silabus dan RPP? 


\section{METODE PENELITIAN}

Jenis penelitian ini adalah Penelitian Tindakan Kelas (PTK). Arikunto (2007) mengemukakan bahwa Penelitian Tindakan Kelas merupakan suatu pencermatan terhadap kegiatan belajar berupa sebuah tindakan, yang sengaja dimunculkan dan terjadi dalam sebuah kelas secara bersama. Kemudian Kusumah \& Dwitagama (2010) menyebutkan bahwa PTK merupakan penelitian yang dilakukan oleh guru di kelasnya sendiri dengan cara merencanakan, melaksanakan, dan merefleksikan tindakan secara kolaboratif dan partisipatif dengan tujuan memperbaiki kinerja guru sehingga hasil belajar siswa dapat meningkat. Penelitian tindakan kelas yang digunakan dalam penelitian ini mengacu pada Model Kemmis \& McTaggrat yang terdiri dari empat komponen, yaitu perencanaan (planning), tindakan (acting), pengamatan (observing) dan refleksi (reflecting). Sesuai dengan fokus permasalahan maka yang menjadi subjek dalam penelitian ini adalah guru-guru di SD Negeri Liunggunung Kecamatan Mangkubumi Kota Tasikmalaya.

\section{HASIL DAN PEMBAHASAN}

a. Kompetensi Guru Sebelum Kegiatan Penelitian

1. Kuantitas silabus dan RPP tahun pelajaran $2018 / 2019$

Pada akhir tahun pelajaran 2018/2019, peneliti mencatat guru yang menyetorkan perangkat pembelajaran untuk ditandatangani. Lebih jelasnya, prosentase jumlah guru yang mengumpulkan perangkat pembelajaran sebelum kegiatan disajikan pada Tabel 1.

Tabel 1. Rekapitulasi Guru yang Menyetorkan Perangkat Pembelajaran

\begin{tabular}{|c|c|c|c|c|}
\hline No & Komponen & $\begin{array}{c}\text { Jumlah } \\
\text { Seharusnya }\end{array}$ & $\begin{array}{c}\text { Yang } \\
\text { Mengumpulkan }\end{array}$ & $\begin{array}{c}\% \text { yang } \\
\text { mengumpulkan }\end{array}$ \\
\hline 1 & Standar Isi Mapel & 11 & 11 & 100,00 \\
\hline 2 & Kalender Pendidikan & 11 & 11 & 100,00 \\
\hline 3 & Program tahunan & 11 & 6 & 54,55 \\
\hline 4 & Program semester & 11 & 8 & 72,73 \\
\hline 5 & KKM & 11 & 8 & 72,73 \\
\hline 6 & Analisis Tujuan Mapel & 11 & 11 & 100,00 \\
\hline 7 & Analisis Materi Mapel & 11 & 0 & - \\
\hline 8 & $\begin{array}{l}\text { Analisis pemetaan } \\
\text { SK/KD }\end{array}$ & 11 & 11 & 100,00 \\
\hline 9 & Silabus & 11 & 9 & 81,82 \\
\hline 10 & RPP & 11 & 6 & 54,55 \\
\hline 11 & $\begin{array}{l}\text { Agenda } \\
\text { Harian }\end{array}$ & 11 & 9 & 81,82 \\
\hline 12 & $\begin{array}{l}\text { Pelaksanaan Prog. } \\
\text { Semester }\end{array}$ & 11 & 4 & 36,36 \\
\hline 13 & Daftar hadir siswa & 11 & 11 & 100,00 \\
\hline 14 & Daftar nilai & 11 & 11 & 100,00 \\
\hline 15 & $\begin{array}{l}\text { Analisis Hasil Ulangan } \\
\text { harian }\end{array}$ & 11 & 2 & 18,18 \\
\hline 16 & Analisis hasil UTS & 11 & 7 & 63,64 \\
\hline 17 & Analisis butir soal & 11 & 7 & 63,64 \\
\hline 18 & Bank soal & 11 & 5 & 45,45 \\
\hline 19 & $\begin{array}{l}\text { Program perbaikan dan } \\
\text { Pengayaan }\end{array}$ & 11 & 2 & 18,18 \\
\hline 20 & $\begin{array}{l}\text { Laporan hasil perbaikan } \\
\text { Jumlah }\end{array}$ & $\begin{array}{c}11 \\
220\end{array}$ & $\begin{array}{c}0 \\
128\end{array}$ & $\begin{array}{r}- \\
1163,64\end{array}$ \\
\hline
\end{tabular}

Dari Table 1 jelas terlihat bahwa data dasar guru yang meyusun perangkat pembelajaran adalah sebesar $58,18 \%$. Dari silabus dan RPP yang terkumpul ini, kemudian penulis melakukan penelaahan terhadap kualitas dari perangkat pembelajaran yang dikumpulkan terutama pada silabus dan RPP. 


\section{Kualitas Silabus dan RPP Guru}

Kualitas silabus dan RPP yang dibuat oleh guru SD Negeri Liunggunung Kecamatan Mangkubumi Kota Tasikmalaya secara umum dapat dikatakan kurang baik. Hal ini dikarenakan masih banyak silabus dan RPP yang masih menggunakan format lama dan terkesan tidak original (copy paste dari orang lain). Hal ini terlihat dari tidak timbulnya visi dan misi serta tujuan sekolah pada silabus dan RPP yang dibuat oleh guru. Hasil penilaian disajikan pada Tabel1.

Tabel 2. Daftar Nilai Kualitas Silabus dan RPP

\begin{tabular}{lcccc}
\hline No & Nama Guru & Silabus & RPP & Rata-rata \\
\hline 1 & S1 & 75 & 60 & 68 \\
2 & S2 & 75 & 69 & 72 \\
3 & S3 & 61 & 70 & 66 \\
4 & S4 & 61 & - & 31 \\
5 & S5 & 64 & 75 & 70 \\
6 & S6 & 64 & 60 & 62 \\
7 & S7 & 64 & 60 & 62 \\
Nilai Terendah & & 61 & 60 & 31 \\
Rata-rata & & 66,29 & 56,29 & 61,57 \\
Jumlah $<70$ & & 5 & 5 & 5 \\
Jumlah $>70$ & & 2 & 2 & 2 \\
Prosentase $<70$ & & 71.42 & 71.42 & 71.42 \\
\hline
\end{tabular}

Dari Tabel 2, jelas terlihat bahwa kualitas silabus da RPP SD Negeri Liunggunung Kecamatan Mangkubumi Kota Tasikmalaya masih sangat rendah. Dari 7 orang guru yang silabus dan RPP-nya dianalisa oleh peneliti, hanya rata-rata $28.57 \%$ guru yang memiliki silabus dan RPP yang sesuai dan dinilai baik. Lebih rinci, prosentase guru yang silabusnya baik (di atas 70 ) adalah $28.57 \%$.

\section{b. Kompetensi Guru dalam menyusun silabus setelah siklus ke-1}

\section{Kuantitas Guru yang menyusun silabus dan RPP setelah siklus ke-1}

Pada rapat awal tahun pelajaran 2018/2019, peneliti memerintahkan kepada seluruh guru untuk membuat perangkat pembelajaran. Setelah berjalan selama hampir tiga bulan, peneliti mengumumkan kepada seluruh guru bahwa pada bulan Nopember 2018 akan dilakukan supervise terhadap administrasi guru. Pada siklus ini seluruh guru diminta untuk mengumpulkan perangkat pembelajaran tersebut. Selanjutnya peneliti melakukan analisis dan penilaian terhadap kuantitas guru yang menyetorkan perangkat pembelajaran terutama silabus dan RPP. Dari hasil perhitungan peneliti terhadap jumlah guru yang mengumpulkan silabus dan RPP didapatkan data pada Tabel 3.

Tabel 3. Rekapitulasi Perhitungan Pengumpulan Silabus dan RPP Pada Siklus I

\begin{tabular}{|c|c|c|c|c|c|c|c|}
\hline \multirow[b]{2}{*}{ No } & \multirow[b]{2}{*}{ Kelas } & \multicolumn{3}{|c|}{ Silabus } & \multicolumn{3}{|c|}{ RPP } \\
\hline & & $\begin{array}{c}\text { Seharus } \\
\text { Nya }\end{array}$ & $\begin{array}{l}\text { Mengumpul } \\
\text { Kan }\end{array}$ & $\%$ Mengumpulkan & $\begin{array}{c}\text { Seharus } \\
\text { nya }\end{array}$ & $\begin{array}{c}\text { Mengumpul } \\
\text { Kan }\end{array}$ & $\%$ Mengumpulkan \\
\hline 1 & $\mathrm{I}$ & 3 & 2 & 66,66 & 3 & 2 & 100 \\
\hline 2 & $\|$ & 3 & 3 & 100 & 3 & 2 & 100 \\
\hline 3 & III & 1 & 1 & 100 & 1 & 1 & 100 \\
\hline 4 & IV & 1 & 0 & 0 & 1 & 0 & 0 \\
\hline 5 & V & 1 & 0 & 0 & 1 & 1 & 0 \\
\hline 6 & VI & 1 & 1 & 100 & 1 & 1 & 100 \\
\hline \multicolumn{2}{|c|}{ Prosentase } & \multicolumn{6}{|c|}{70} \\
\hline
\end{tabular}


Dari data jumlah guru yang mengumpulkan silabus dan RPP pada awal siklus 1, dapat terlihat bahwa dengan informasi adanya supervise akademik terhadap guru dapat meningkatkan kuantitas jumlah guru yang menyusun silabus dan RPP yang sebelumnya hanya 60\%, mengalami peningkatan kuantitas menjadi $70 \%$. Dari data tersebut juga dapat dilihat adanya guru yang hanya menyerahkan silabus tanpa dengan RPP-nya serta ada yang belum menyetorkan silabus dan RPP.

\section{Kualitas silabus dan RPP setelah siklus ke-I}

Sebelum melakukan supervise individual terhadap seluruh guru terutama kepada guru yang belum menyetorkan silabus dan RPP. Peneliti melakukan analisa kedua terhadap sampel silabus dan RPP yang dibuat oleh guru. Hasil analisis kualitas silabus dan RPP tersebut dapat terlihat pada Table 4.

Tabel 4. Rekapitulasi penilaian silabus dan RPP pada siklus I

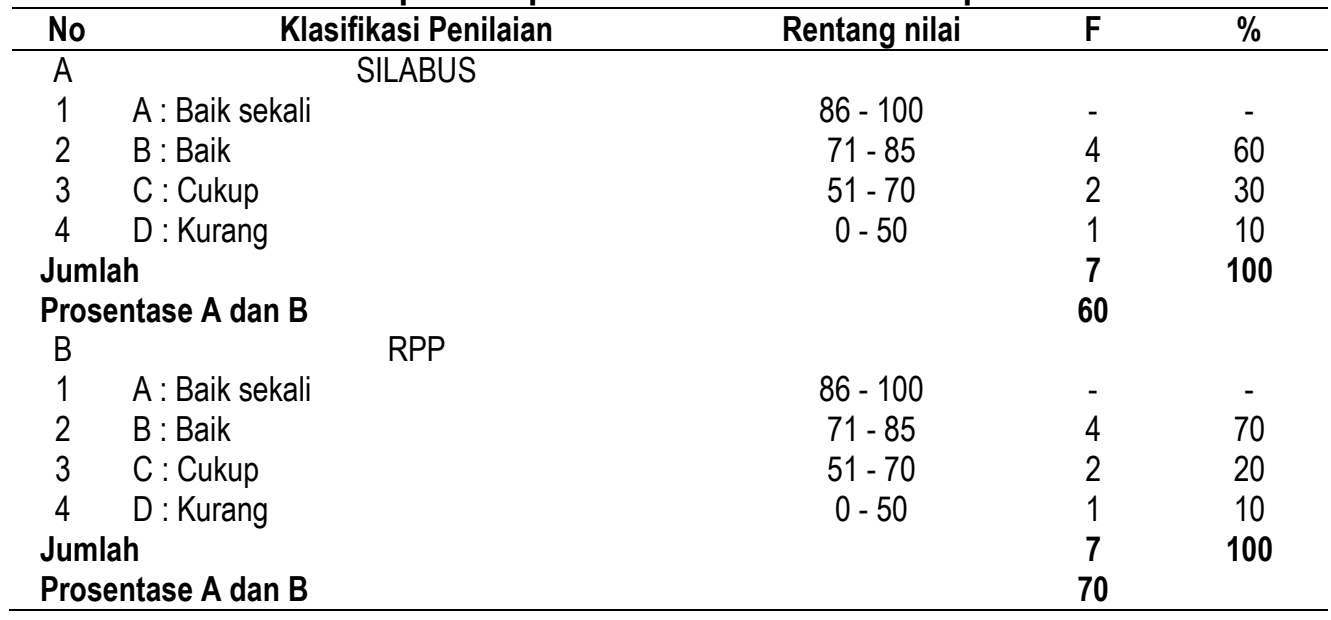

Sementara itu, hasil analisa kualitas penyusunan silabus dan RPP setelah dilakukan supervise individual (setelah direvisi) dapat dilihat pada Tabel 5.

Tabel 5. Rekapitulasi penilaian silabus dan RPP setelah revisi (siklus I)

\begin{tabular}{ccccc}
\hline No & \multicolumn{1}{c}{ Klasifikasi Penilaian } & Rentang nilai & F & $\%$ \\
\hline A & SILABUS & & & \\
1 & A : Baik sekali & $86-100$ & 2 & 20 \\
2 & B : Baik & $71-85$ & 3 & 60 \\
$3 \quad$ C: Cukup & $51-70$ & 2 & 20 \\
$4 \quad$ D : Kurang & $0-50$ & - & - \\
Jumlah & & 7 & 100 \\
Prosentase A dan B & & & 80 & \\
B & RPP & & & \\
$1 \quad$ A : Baik sekali & & $86-100$ & 2 & 20 \\
$2 \quad$ B : Baik & $71-85$ & 4 & 70 \\
$3 \quad$ C: Cukup & $51-70$ & 1 & 10 \\
$4 \quad$ D : Kurang & $0-50$ & - & - \\
Jumlah & & 7 & \\
Prosentase A dan B & & 90 & \\
\hline
\end{tabular}

Hasil analisa revisi silabus dan RPP pada Tabel 5 memperlihatkan terjadinya peningkatan kualitas silabus dan RPP. Dimana kualitas A dan B meningkat dari 60 dan $70 \%$ menjadi 80 dan $90 \%$. Dari sini pula terlihat bahwa jumlah guru yang mengumpulkan sampel silabus dan RPP menjadi $100 \%$. 


\section{c. Kompetensi guru menyusun silabus dan RPP setelah siklus ke-II}

Pada siklus kedua ini, penelitian dilanjutkan dengan menganalisa/menguji keaslian silabus dan RPP yang disusun oleh guru. Metode yang digunakan adalah dengan melakukan supervise kelas. Dari pelaksanaan rencana pembelajaran ini,dapat terlihat keaslian penyusunannya. Hasil dari analisa penguat tersebut, menunjukkan bahwa silabus dan RPP yang dikumpulkan benar disusun oleh guru yang bersangkutan. Karena terjadi kesesuaian skenario antara perencanaan dan pelaksanaan di kelas. Data kesesuaian tersebut dapat dilihat dari Tabel 6.

Tabel 6. Hasil Penilaian Supervisi Kelas

\begin{tabular}{clccc}
\hline No & \multicolumn{1}{c}{ Klasifikasi Penilaian } & Rentang nilai & F & $\%$ \\
\hline 1 & A : Sesuai & $76-100$ & $\mathbf{5}$ & 80 \\
2 & B : Cukup sesuai & $51-75$ & $\mathbf{2}$ & 20 \\
3 & C : Kurang sesuai & $26-50$ & - & - \\
4 & D : Tidak sesuai & $0-25$ & - & - \\
Jumlah & & $\mathbf{7}$ & $\mathbf{1 0 0}$ \\
\hline
\end{tabular}

Dari hasil perhitungan pada Tabel 6, maka dapat ditarik sebuah kesimpulan bahwa silabus dan RPP yang dikumpulkan guru adalah bersifat original. Hal ini terlihat dengan cukup besarnya guru mampu melaksanakan pembelajaran sesuai dengan rencana yang dibuat. Kegiatan supervisi akademik jika dilaksanakan secara berkala dapat meningkatkan kompetensi pedagogik guru (Prihono, 2014). Kegiatan supervisi akademik yang diaktualisasikan dalam supervisi kepala sekolah dapat meningkatkan kinerja guru dengan tujuan mempertinggi kualitas proses pembelajaran demi tercapainya mutu pendidikan yang diharapkan (Ramadhan, 2017). Supervisi akademik kepala sekolah dapat meningkatkan Kompetensi Guru dalam menyusun Rencana Pelaksanaa Pembelajaran (Arman, 2017).

\section{KESIMPULAN}

Berdasarkan hasil penelitian, kami dapat menyimpulkan bahwa:1) Supervisi akademik secara berkelanjutan terbukti secara ilmiah dapat meningkatkan kompetensi guru dalam menyusun silabus dan RPP di SD Negeri Liunggunung Kecamatan Mangkubumi Kota Tasikmalaya. Ini terbukti dengan meningkatnya jumlah silabus guru yang baik dari 30\% menjadi $80 \%$ setelah supervise akademik. Selain itu jumlah RPP yang berkualitas baik juga meningkat dari 30\% menjadi $90 \%$; dan 2) Langkah-langkah yang mengakibatkan terjadinya peningkatan kompetensi guru dalam menyusun silabus dan RPP tersebut meliputi langkah-langkah sebagai berikut: a) Pengumuman rencana supervisi terhadap guru; b) Pelaksanaan supervise individual, dimana setiap guru diminta mempresentasikan silabus dan RPP-nya kepada kepala sekolah, kemudian kepala sekolah memberikan masukan terhadap kekurangan silabus dan RPP guru; c) Untuk mengecek originalitas silabus dan RPP yang disusun guru,kepala sekolah melakukan supervise kelas. Hal ini dilakukan untuk menyesuaikan rencana yang dimuat dalam silabus dan RPP dengan penerapannya di kelas. Jika sesuai maka dapat dipastikan, kompetensi guru dalam menyusun silabus dan RPP tersebut benar (bukan jiplakan atau dibuatkan orang lain). Jika banyak ketidaksesuaian maka ada kemungkinan silabus dan RPP tersebut dibuatkan oleh orang lain.

\section{REKOMENDASI}

Untuk kepala sekolah, pelaksanaan supervise individual sangat cocok digunakan untuk meningkatkan kompetensi guru dalam menyusun silabus dan RPP yang selama ini masih menjadi administrasi yang masih sulit diminta dari guru-guru kita. Untuk mengujinya, kita dapat menggunakan supervisi kelas. 


\section{UCAPAN TERIMA KASIH}

Ucapan terima kasih ditujukan kepada guru-guru SD Negeri Liunggunung Kecamatan Mangkubumi Kota Tasikmalaya yang telah mendukung terhadap pelaksanaan penelitian ini.

\section{DAFTAR PUSTAKA}

Arikunto, S. (2006). Prosedur Penelitian Suatu Pendekatan Praktik. Jakarta: Rineka Cipta.

Arman, A. (2017). Upaya Peningkatan Kompetensi Guru dalam Menyusun Rencana Pelaksanaan Pembelajaran Melalui Supervisi Akademik Kepala Sekolah Di SMAN 1 Lembah Melintang Kabupaten Pasaman Barat. Jurnal Manajemen Pendidikan, 1(1), 55-62.

Bahri, S. (2014). Supervisi akademik dalam peningkatan profesionalisme guru. Visipena Journal, 5(1), 100-112.

Danim, S. (2002). Inovasi Pendidikan dalam Upaya Peningkatan Profesionalisme Tenaga Kependidikan. Bandung: CV Pustaka Setia.

Kusumah, W \& Dwitagama. (2010). Mengenal Penelitian Tindakan Kelas. Jakarta: PT INDEKS.

Prihono, H. (2014). Model Supervisi Akademik Berbasis Evaluasi Diri Melalui MGMP Sekolah Untuk Meningkatkan Kompetensi Pedagogik Guru SMK di Kabupaten Wonogiri. Educational Management, 3(2), 126-132.

Ramadhan, A. (2017). Pengaruh Pelaksanaan Supervisi Akademik Pengawas Sekolah Dan Supervisi Kepala Sekolah Terhadap Kinerja Guru SMK Negeri Di Kabupaten Majene. Journal of Educational Science and Technology (EST), 3(2), 136-144.

Sopiah, E, S., Effendi, A., \& Sunaryo, Y. (2020). Analisis Kemampuan Berpikir Kreatif Matematis Siswa Kelas VIII pada Materi Sistem Persamaan Linear Dua Variabel (SPLDV). J-KIP (Jurnal Keguruan dan IImu Pendidikan), 1 (2), 1-10. 
J-KIP (Jurnal Keguruan dan IImu Pendidikan) Vol. 2, No. 1, Februari 2021, pp. 1-8 e-ISSN 2722-6069 